\title{
The Role of Stakeholders in the Handling of the Exposure Flood Disaster of Lake Tempe in South Sulawesi
}

\author{
Retno Sunu Astuti ${ }^{1}$, Budi Puspo Priyadi ${ }^{2}$, Zainal Hidayat ${ }^{3}$ \\ \{retnosunu@gmail.com¹, budipuspo@gmail.com², zainal.hida56@gmail.com³ \\ Universitas Diponegoro, Indonesia ${ }^{1,2,3}$
}

\begin{abstract}
Lake Tempe flooding was a routine phenomenon happening hundreds of years from water entering several rivers, namely the Walannae River, Bila River, Batu-Batu River and Bilokka River. When the rainy season arrived, the water discharge was abundant so that it inundated the lake and the surrounding residential areas were affected. The decreasing of vegetation of perennials in the upstream area resulted in erosion which then accelerated the rate of sedimentation so that the depth of the lake decreased and it impacted on the extent of flood exposure. In addition, water hyacinth which naturally grew wild increasingly reduced the capacity of the lake even when flooding was carried away by the flow of water. In handling the Lake Tempe flood disaster which was routine in nature it involved five parties (penta helix), including the government, business (private), academics and experts, civil society and the mass media. Each of the five parties was each supported by a variety of elements having the role of mutual support among the elements. The objective of this research is to discover the role of the five parties, including their elements, in handling of the exposure flood disaster of Lake Tempe. In mitigating the Lake Tempe flood disaster, the government was supported by fifteen elements including elements of the Indonesian National Army (TNI), the Indonesian National Police (POLRI), BPBD, Disaster Management Operational Control Center (PUSDALOP), Rapid Reaction Team (TRC) ), Social Service, Disaster Preparedness Organization (TAGANA), Fire and Rescue Service, Civil Service Police Unit (Satpol PP), Health Service, Transportation Service, Lamadukkelleng General Hospital, Bina Marga Service Construction and Spatial Management Services, and District and Village government. Apart from government elements, the responsiveness of the community in dealing with the Lake Tempe flood in Wajo Regency was not only from the fishing community but also from the Wajo people at large. Community response to participate in helping communities affected by Lake Tempe floods was very high. This proved that many community organizations are involved to help provide assistance in dealing with floods.
\end{abstract}

Keywords: Primary Stakeholders, Flood Disasters, Role.

\section{Introduction}

Geological and geographical characteristics make Indonesia experiencing almost all forms of disasters, especially natural disasters so that Indonesia is known as a "disaster laboratory". Trends in the occurrence of natural disasters in Indonesia in the past 10 years show that the dominant disaster occurring in the territory of Indonesia is the flood disaster [1]. 
The complexity of disasters in Indonesia, especially floods, must be handled by the government and the community. The wider social, economic impacts are indeed not easy to overcome quickly by the government, although it is as the party responsible for public safety $[2]$.

Important issues in disaster management in Indonesia are as follows: (1) the lack of socialization of disaster management legislation; (2) limited human resources related to disaster management; (3) there are still areas that do not yet have a disaster management plan and a regional action plan for disaster risk reduction; (4) disaster management materials have not been integrated with various fields, ranging from staffing and apparatus education and training; (5) the concept of integrative thinking that the protection of the community from the threat of disaster by the government and regional governments requires public awareness that the responsibility of disaster management is also their responsibility; and (6) there is a paradigm shift in disaster management, one of which is the role of centralization to decentralization or conventional handling to a holistic and comprehensive pattern.

One area in Indonesia that experiences floods every year is floods that occur due to overflowing of Lake Tempe. This flood is understood as a lake exposure flood. Exposure floods are floods that occur due to overflowing river or lake water [3]. Overflow occurs because the capacity of water capacity in a river or lake is not balanced at a certain period of time. Exposure flooding usually occurs in areas or areas around lakes or rivers that have relatively flat contours. The area that was flooded due to overflowing water is called a flood exposure area (floodplain). In the rainy season, flood exposed areas or areas can form large inundations so that the river or lake area becomes larger than usual. This happens because of the unification or connection of the river or small lake around it. Conversely, during the dry or dry season, the flood exposure area becomes dry land. [4].

The government currently recognizes that it does not have a clear SOP on disaster management. Disaster management requires specific rules for each type of disaster and its region. Existing regulations that are currently used by the government, namely Law Number 24 of 2007 concerning Disaster Management which is then implemented through a Regulation of the Head of the BNPB makes an emergency response SOP. This emergency response only regulates BNPB's position in disaster management and does not regulate further or in detail the positions or tasks of other stakeholders involved in disaster management.

The current disaster management regulation at the regional level is neither detailed nor specific stating in how to handle flooding. It is clear that almost every year there is a flood, but there are no rules or SOP on how to deal with flood specifically. In the case of flood disaster management in the province of South Sulawesi, specifically the exposure flood of Lake Tempe, it can be identified what the initial social capital and collaborative network in dealing with the flood is. This is reflected in the ability of the community to survive and adapt to the phenomenon of the exposure flood of the lake. The risk of floods that occur every year has become a part of their lives. Community adaptation can be seen from the readiness of residential architecture and logistics management. The weakness of the regulation for handling the exposure floods of Lake Tempe is reflected in the spatial planning of the Lake Tempe area. In the study of the Lake Tempe Rescue Movement (Germadan) compiled by the Ministry of Environment there has been no zoning for the use of Lake Tempe. Another disadvantage is that flood management is only reactive in nature, not an integrated approach or vulnerability approach.

South Sulawesi Governor Regulation Number 35 Year 2015 Regarding the Work Plan of the South Sulawesi Provincial Government in 2016 states that Lake Tempe is categorized as an area prone to natural disasters. The Regulation of Wajo Regent Number 61 of 2014 
concerning the Main Duties and Functions of Structural Position of the Regional Disaster Management Agency of Wajo Regency, mandates the Regional Disaster Management Agency (BPBD) of Wajo Regency for the preparation of regional and technical policies regarding the technical implementation of disaster management. The implementation of instructions of the Regent's Regulations have not yet found any policy or technical implementation instructions in the form of documents so that the implementation of disaster management is carried out without the support of completeness of technical policies, specifically the flood disaster exposed by Lake Tempe. Mapping of stakeholders is an important activity in order to provide resolution of disaster management through the distribution of roles so that people do not become victims of government policies and place the victims of the disaster as socially, economically and politically empowered groups.

Stakeholders are all parties in the community, be it individuals, community groups or communities, who have a relationship and interest in an issue/problem within the organization/environment that is being raised. Stakeholders can be interpreted as stakeholders or interested parties. Stakeholder mapping and analysis is a way to gain an understanding of who are the stakeholders involved in a collaborative network of disaster management. With this understanding through mapping, it will be known their potential roles and contributions which are the basis of the success of collaborative networks. Stakeholder mapping is important because policy makers can identify important actors in the process of policy formulation and policy implementation. Stakeholder mapping can help determine the best way to design activities.

Freeman (1984) states that stakeholders are a group of people or individuals who influence each other and are influenced by the achievement of certain goals of the organization. Some categories of stakeholder group divisions include: a) Primary Stakeholders are stakeholders who have a direct interest relationship with a policy, program and project, b) Secondary Stakeholders (supporters), i.e. parties not directly related to a policy, program, or project, and c) Key Stakeholders, namely the executive element based on its level (legislative and agency) which has legal authority to make decisions. In this research, mapping was carried out on the stakeholders involved and what the roles of each of these stakeholders were in relation to dealing with the exposure flood of Lake Tempe in South Sulawesi.

This research use penta helix theory to mapping the stakeholder's role in handling the disaster management of Lake Tempe. Penta helix means the collaboration between five stakeholders to achieve a policy that is supported by various resources that synergic ally interacted [5]. The five stakeholders defined in the penta helix theory are: Government, Private, Academicians, Non-governmental organization (NGO) or Civil Society, and Mass Media. This research found that these five stakeholders played such important role, as they synergized in the case of disaster management of flood exposure in Lake Tempe.

\section{Research Method}

This research is a type of research with a descriptive qualitative method, trying to identify stakeholders involved in the handling of the exposure flood disaster of Lake Tempe in South Sulawesi. The sampling method is non-probability sampling with snowball sampling technique. Primary data sources in this research were obtained through in-depth interviews and FGDs with community leaders and stakeholders involved in disaster management, while secondary data were collected through reports prepared by the government as the main 
responsible person for disaster management. Data collection and data analysis run simultaneously according to the cycle in the Operational Component model delivered by Miles and Huberman [6].

\section{Result and Discussion}

\subsection{Stakeholders Mapping in Handling Lake Tempe Flood Disaster}

Floods in Lake Tempe are floods that occurred annually because they received water from five neighboring districts, namely Barru, Enrekang, Sidrap, Maros, Bone and Soppeng. The incident happened twice in November, December, January, and February, then in April, May, June, and July. The highest flood intensity occurred in December and May. The phenomenon of Lake Tempe flooding had been going on for a long time so that the surrounding community was accustomed to it even though it sometimes caused casualties. The frequent flooding the community around Lake Tempe had culturally local wisdom which was then often used as a basis for planning while they were facing disasters [7][8]. The routine nature of the Lake Tempe flood had finally become an annual agenda of various parties, especially local governments whose areas were affected, namely in Sidenreng Rappang, Soppeng and Wajo Regencies. Wajo Regency had the most area in Lake Tempe, which is 54.6 percent, Soppeng District 34.6 percent, and Sidrap District 10.8 percent. The area of Lake Tempe itself is around $350 \mathrm{~km} 2$ in which during the rainy season the surface area of the water becomes wider. Musdah and Husein's research (2014) concluded that there had been efforts to deal with floods more systematically, namely by making local regulations in each district.

Lake Tempe routine flooding was more complicated because of the siltation in the bottom of the lake due to sedimentation of mud from the water entering the lake. The water comes from Walannae River, Bila River, Batu-Batu River and Bilokka River. In addition, it was also due to water hyacinth which naturally grew wild thereby reducing the capacity of the lake. Water hyacinth had also become a danger when the plant colony was dragged by the flow of water and hit stilt houses around the edge of the lake. The thrust of the water hyacinth colony could knock down the construction of houses on stilts so as to have an impact on its inhabitants. The government through the Ministry of PUPR then built a water hyacinth barrier on the edge of the lake functioning to stop the rate of water hyacinth when flooding happened. Water hyacinth could already be used for handicraft materials and materials for making biogas, organic fertilizer and various handicraft products. However, the growth rate of water hyacinth was not proportional to the capacity that could be processed so that it remained a threat to fish in the lake area.

Structurally the competent party in managing Lake Tempe floods is the Regional Disaster Management Agency. BPBD acts as the coordinator when the floods and the following disasters occur. Disaster management is an activity which includes the one before, during and after a disaster so that a condition returns to the good condition. In disaster management the involvement of various parties is needed so that a condition that disrupts the life and suffering of the community is immediately overcome. The identification of various parties in managing the Lake Tempe flood disaster is intended to find out which parties are involved in the Lake Tempe flood disaster management effort. From the identification results, in addition to trying to describe the relationship between the parties, it also identified where the status or position of each party is meant whether occupying the position as a primary, 
secondary or tertiary party. In handling the Lake Tempe flood disaster involving five parties (penta helix) which included the government, business (private), academics and experts, civil society and the mass media. Each of the five parties was each supported by a variety of elements that had the role of mutual support between one element to another.

\subsection{Government}

In handling the Lake Tempe flood disaster, the government was supported by fifteen elements including elements of the Indonesian National Army, the Republic of Indonesia Police, Senkom Mitra Polri, BPBD, Disaster Management Operations Control Center, Rapid Reaction Team, Social Service, Disaster Preparedness Officer, Fire Service and Rescue, the Civil Service Police Unit, the Health Service, the Transportation Service, the Lamadukkelleng General Hospital, the Bina Marga Office of Construction Services and Spatial Planning, as well as the District and Village Government. Of the fifteen elements each had a different but mutually supportive position.

The involvement of the fifteen government elements was large enough, but not comparable with the scale of the flooding that occurred. Lake Tempe flood was still classified as low to moderate scale flood. Lake Tempe Flood was a routine incident happening every year so that the community had resilience in carrying out adaptations or efforts to save themselves. Fisher's activity only diverted from being able to find fish because of the swift flow of water while it was flooding. The involvement of many elements of the government in handling the Lake Tempe flood disaster could lead to problems of coordination and workload proportions.

\subsection{Private}

The private sector participations in disaster management was a form of concern shown by the private sector in taking part in alleviating the burden of suffering on society. There were nine elements of the private sector involved in flood mitigation, namely the Sengkang Central Traders Forum, Bank Rakyat Indonesia, Bank Mega, Bank Sulselbar, Bank Negara Indonesia, Perum Pegadaian, Jasa Marga, Energy Equity Epic (Sengkang) Pty. LTD, as well as PT. Sengkang Energy. They participated in raising funds and assistance in coordination with the Wajo Regency BPBD as a form of social concern for the private sector.

\subsection{Academics and Experts}

In the effort to overcome the Lake Tempe flood disaster so far there had only been one tertiary institution involved, namely Puangrimaggalatung University. In addition, there were elements of Scouting through Caring Scout activities that also help disaster relief efforts. The minimal role of tertiary institutions directly involved in the handling of the Lake Tempe flood disaster showed that the university's share had not been maximized. Although the results of the search for various scientific studies such as journals found in various scientific studies from various scientific disciplines that studied the Lake Tempe flood problem such as academics from UNHAS, IPB, LIPI, and from several other universities, also from the Ministry of PUPR. Issues relating to Lake Tempe were not solely a problem of flooding and its impact on the community but were also related to environmental issues, land tenure, threats of weeds, endemic animals and fish and so on. 


\subsection{Civil Society}

Civil society is a society that is bound by social solidarity and integration based on social values and norms so that the various problems faced by society will be solved together. The Wajo tribe community also has a bond of solidarity and social integration that is guided by values and norms, as well as traditions that apply for generations. One of the traditions of the Wajo people, especially the Tempe Lake fishing community is maccera 'tappareng. The maccera 'tappareng tradition is a ritual offering ceremony in the form of a buffalo head to be submerged in the middle of a lake led by a maccua tappareng (Mustamin and Kamaruddin, 2016: 251-252). This tradition is intended to offer prayers so that the Tempe Lake fishing community is given an abundance of wealth in the form of catch fish. With this tradition the community is able to develop their abilities in dealing with natural conditions, not least the readiness of the fishing community in dealing with flood conditions. They are also still strong in holding customs so that even in a state of flooding they strive to obey them [9]. Based on an interview with one of the fishermen on Lake Tempe, namely Mr. Bahar, the customs are still obeyed by the fishermen who are around the lake.

The response of the community in dealing with floods was not only shown by the fishing community, but also by the Wajo people at large. This is evident that many community organizations were involved in helping the community by providing assistance in dealing with floods. Community organizations included: LPBI-NU, SAR Orari, PMI, Lazimu, Destana, Indidu Community Elements, ACT, Karang Taruna PPI and MPBI.

\subsection{Mass Media}

Dealing with the flood disaster incident, the mass media was very concerned about the Lake Tempe flood event that occurred every year, including print media, electronic media and internet mass media. Based on the results of investigations conducted by researchers on the development of mass media in South Sulawesi Province that there are 3 daily print media, 33 weekly print media, 32 monthly mass media, 3 television stations, and 14 online mass media which all of these are directly or indirectly has a role in reporting the Lake Tempe flood event in Wajo District.

\section{Conclusion}

The phenomenon of routine flooding in Lake Tempe has caused a variety of responses, both from affected communities and the government. The government, in this case as the primary stakeholder, had been well prepared in facing flooding because it happened routinely twice a year. In terms of disaster management, the involvement of the five parties (penta helix) had become more organized, but what needs to be watched was the natural damage factor, especially in the upstream area and also the rate of lake sedimentation. It needs to be fully anticipated by involving various parties so that the magnitude of the flood can be overcome.

\section{References}

[1] Badan Nasional Penanggulangan Bencana, "Data Informasi Bencana Indonesia (DIBI)," 
Nopember 2018, 2018. [Online]. Available: http://dibi.bnpb.go.id/dibi/.

[2] B. Chamsah, "Kebijakan Penanggulangan Bencana di Indonesia," Makal. Semin. Nas. Manaj. Bencana, Univ. Tarumanagara, 2007.

[3] A. Goudie, "Encyclopedia of geomorphology. Volume 1," Routledge. p. 1156, 2004.

[4] PU, "Buku Informasi Statistik Pekerjaan Umum 2013," 2013.

[5] C. Ansell and A. Gash, "Collaborative governance in theory and practice," J. Public Adm. Res. Theory, vol. 18, no. 4, pp. 543-571, 2008.

[6] A. M. Miles, Matthew., \& Huberman, Analisis Data Kualitatif. Jakarta: UI Press, 1992.

[7] F. Surur, S. R. P. Sitorus, and I. Agusta, "Pertimbangan Aspek Sosial Budaya dan Kearifan Lokal dalam Pengembangan Kawasan Danau Tempe Provinsi Sulawesi Selatan," J. Tataloka, vol. 16 , no. 3 , p. 168, 2014.

[8] A. F. Asti, "Bencana Alam dan Budaya Lokal: Masyarakat Lokal Terhadap Banjir Tahunan Danau Tempe Di Kabupaten Wajo, Propinsi Sulawesi Selatan," Annu. Int. Conf. Islam. Stud. XII, no. 3, pp. 1429-1445, 2016.

[9] I. M. Hamka and H. Naping, "Nelayan Danau Tempe: Strategi Adaptasi Masyarakat dalam Menghadapi Kondisi Perubahan Musim,” ETNOSIA J. Etnogr. Indones., vol. 4, no. 1, p. 59, 2019. 